\title{
Commentary: Beyond C4: Analysis of the complement gene pathway shows enrichment for IQ in patients with psychotic disorders and healthy controls
}

\author{
Liam G. Coulthard ${ }^{1,2 \star}$ and Trent M. Woodruff ${ }^{2}$ \\ ${ }^{1}$ Kenneth G Jamieson Department of Neurosurgery, Royal Brisbane and Women's Hospital, Brisbane, QLD, Australia, \\ ${ }^{2}$ Faculty of Medicine, The University of Queensland, St Lucia, QLD, Australia
}

Keywords: complement - immunological terms, neurodevelopment, neuroimmunology, C5aR, synaptic pruning, SERPING1, schizophrenia

\section{A Commentary on}

OPEN ACCESS

Edited by:

Nicole Thielens,

UMR5075 Institut de Biologie

Structurale (IBS), France

Reviewed by:

Robert Braidwood Sim,

University of Oxford, United Kingdom

Bryan Paul Morgan,

Cardiff University, United Kingdom

*Correspondence:

Liam G. Coulthard

l.coulthard@uq.edu.au

Specialty section:

This article was submitted to

Molecular Innate Immunity,

a section of the journal

Frontiers in Immunology

Received: 09 October 2019 Accepted: 20 November 2019 Published: 04 December 2019

Citation:

Coulthard LG and Woodruff TM (2019) Commentary: Beyond C4: Analysis of the complement gene pathway shows enrichment for $I Q$ in patients with psychotic disorders and healthy controls. Front. Immunol. 10:2853.

doi: 10.3389/fimmu.2019.02853
Beyond C4: Analysis of the complement gene pathway shows enrichment for IQ in patients with psychotic disorders and healthy controls

by Holland, J. F., Cosgrove, D., Whitton, L., Harold, D., Corvin, A., Gill, M., et al. (2019). Genes Brain Behav. 18:e12602. doi: 10.1111/gbb.12602

Our interest was piqued by the recent study presented in Genes, Brain and Behavior by Holland et al. (1). They outline an important investigation highlighting the link between complement gene expression and IQ, in both schizophrenic patients and healthy controls. The study demonstrated a broad association between variations in complement gene expression and perturbed neurodevelopment. We were particularly interested to see that the final sentence of the paper stated that "When complement gene-sets are taken as a whole, their relevance is to neurodevelopment, not illness." Their conclusion rightly touches on the emerging understanding of non-immune roles for complement in diverse biological processes (2).

The complement group of proteins is ancient in evolutionary terms. Recognized complement components are found throughout the animal kingdom including in rudimentary diploblastic species (3). In the human adult, complement functions as an essential pillar of the innate immune system. It is activated by various noxious stimuli and results in the production of the anaphylatoxins and membrane attack complex (4). Expectedly, the human collection of complement factors 1-9, associated factors, receptors and regulators is not replicated within jellyfish and their like. These more simple creatures express opsonins, such as $\mathrm{C} 3$, which have historically been thought to function in a basic immune system (3). Whether the more recently discovered, novel roles of complement apply in these ancient species is unknown (5). In the developing mammal we know that the proteins of the complement system are both temporally and spatially separate in their expression $(6,7)$. This, we think, underscores the developmental importance of the other roles of the complement proteins in the absence of the established pathways of activation. There are now several decades of good evidence of separate and distinct roles for complement proteins in both neurodevelopment and general development/regeneration.

In the work by Holland and colleagues, they expand on previous research demonstrating a link between complement and pathogenesis of schizophrenia (1). A recent seminal paper in the fields showed SNPs contributing to altered C4 protein expression resulting in an increased risk of 
schizophrenia. Interestingly, the risk conferred by each SNP was proportional to the magnitude of $C 4 A$ allele overexpression, but not $C 4 B$. This perhaps indicating that there may be subtle differences in the functions of the $\mathrm{C} 4$ alleles that become most apparent in neurodevelopment (8). In addition to C4, other complement factors, such as C5 and SERPING1 have also been shown to be associated with a thin frontal cortex, thought to be pathogenic for schizophrenia (9). Holland and colleagues performed a gene-set analysis, looking specifically for the complement-related genes that are associated with IQ and schizophrenia. Intriguingly, despite previous evidence of individual complement gene association with schizophrenia, there was no whole gene-set association with the disease as determined by MAGMA analysis $(n=105,318)$. There was however a gene-set association with IQ ( $n=269,867,14$ separate cohorts) and 12 individual genes showed a significant individual association with IQ through polygenic score regression analysis in a smaller independent dataset $(n=1,000)$. Regulators of complement action were heavily represented in this group, with SERPING1, a regulator of complement and other plasma enzymes (10), showing the highest association ( $p=3.97 \mathrm{E}-09)$.

To explain their findings, the authors touch upon a key developmental function of the complement system: synaptic pruning. In this role the classical pathway of complement activation acts to selectively tag underactive synapses for removal by microglia (11). Dysregulation can lead to unrefined neural networks in development, or loss of important synapses in degenerative disease (12). The authors are certainly correct that this may be a key mechanism leading to variations in IQ in their samples, however here we highlight other mechanisms that may also contribute.

Neuronal migration during neocortical development is a process dependent on proteins of the lectin pathway of complement activation. Knockdown of MASP1, C3, and SERPING1 results in ectopic migrating neuroblasts, a phenotype rescued by forced expression of a downstream split product of C3 $(13,14)$. The effect of complete knockdown is a dysregulated cortical layering, which would presumably lead to impaired behavioral phenotypes in the resultant adult mice. It is plausible that subtle perturbation of migration, through variations in expression of these genes, may lead to subtle impairments in cognitive development. Perhaps this could account for the SERPING1 association found in the work of Holland et al. (1).

Our own recent findings have shown key roles for the anaphylatoxin receptors, $\mathrm{C} 5 \mathrm{aR} 1$, and $\mathrm{C} 3 \mathrm{aR}$, in directing neural progenitor cell fate. Both receptors are expressed within neural

\section{REFERENCES}

1. Holland JF, Cosgrove D, Whitton L, Harold D, Corvin A, Gill M, et al. Beyond C4: analysis of the complement gene pathway shows enrichment for IQ in patients with psychotic disorders and healthy controls. Genes Brain Behav. (2019) 18:e12602. doi: 10.1111/gbb.12602

2. Hawksworth OA, Coulthard LG, Mantovani S, Woodruff TM. Complement in stem cells and development. Semin Immunol. (2018) 37:4-84. doi: 10.1016/j.smim.2018.02.009 tissue throughout development, from neurulation onwards (15, 16). Here the anaphylatoxin receptors are polarized to the ventricular surface of neural progenitor cells $(6,15,17)$. Despite their similar location, the functions of $\mathrm{C} 3 \mathrm{aR}$ and $\mathrm{C} 5 \mathrm{aR} 1$ seem to be diametrically opposed; $\mathrm{C} 5 \mathrm{aR} 1$ promotes polarity and therefore proliferation of neural progenitors, whereas $\mathrm{C} 3 \mathrm{aR}$ promotes differentiation $(15,17)$.

C3aR and C5aR1 knockout mice exhibit grossly normal physical development, though show cognitive deficits when compared to wild-type controls, both demonstrating impairments in memory $(15,17)$. It is unclear whether this is a result of perturbations to complement-associated roles dictating progenitor fate, migration or synaptic pruning during development (or even due to complement actions in the adult brain). Similarly, the results of Holland and colleagues, where there is association of multiple complement regulator genes with IQ, cannot be attributed solely to one of these developmental roles. Predicting the likely mechanism is fraught with difficulty, not least because the complement system represents a complex web of overlapping pathways and regulators. The common convergence point of all complement pathways remains $\mathrm{C} 3$, with the generation of $\mathrm{C} 3 \mathrm{a}$ and $\mathrm{C} 5 \mathrm{a}$ anaphylatoxins. Therefore, there still exists a possibility that the phenotypes exhibited in the knockout animals, and in the report that forms the subject of this commentary, could be the result of any or all of these novel roles.

To conclude, we commend the work by Holland and colleagues for demonstrating a fascinating link between complement gene polymorphisms and IQ. In the current study they found that SERPING1 had the highest association with IQ (1) and several other key regulators also showed significant association. The study is an important demonstration of the role of complement proteins in normal neurodevelopment. Most interestingly, the pathophysiological mechanisms between altered gene expression and impaired cognition are not yet clear. There are several potential mechanisms that could hold the possibility of an explanation (18), as outlined briefly in this commentary. We remain excited about the future developments in this field, building on this work, to further define how this versatile group of proteins contributes to the normal neurodevelopment.

\section{AUTHOR CONTRIBUTIONS}

All authors listed have made a substantial, direct and intellectual contribution to the work, and approved it for publication.
3. Kimura A, Sakaguchi E, Nonaka M. Multi-component complement system of Cnidaria: $\mathrm{C} 3, \mathrm{Bf}$, and MASP genes expressed in the endodermal tissues of a sea anemone, Nematostella vectensis. Immunobiology. (2009) 214:165-78. doi: 10.1016/j.imbio.2009. 01.003

4. Nesargikar PN, Spiller B, Chavez R. The complement system: history, pathways, cascade and inhibitors. Eur $J$ Microbiol Immunol. (2012) 2:103-11. doi: 10.1556/EuJMI.2. 2012.2.2 
5. Hawksworth OA, Coulthard LG, Woodruff TM. Complement in the fundamental processes of the cell. Mol Immunol. (2017) 84:17-25. doi: 10.1016/j.molimm.2016.11.010

6. Jeanes A, Coulthard LG, Mantovani S, Markham K, Woodruff TM. Coordinated expression of innate immune molecules during mouse neurulation. Mol Immunol. (2015) 68:253-60. doi: 10.1016/j.molimm.2015.09.004

7. McLin VA, Hu C-H, Shah R, Jamrich M. Expression of complement components coincides with early patterning and organogenesis in Xenopus laevis. Int J Dev Biol. (2008) 52:1123-33. doi: 10.1387/ijdb.072465v

8. Sekar A, Bialas AR, de Rivera H, Davis A, Hammond TR, Kamitaki N, et al. Schizophrenia risk from complex variation of complement component 4 . Nature. (2016) 530:177-83. doi: 10.1038/nature16549

9. Allswede DM, Zheutlin AB, Chung Y, Anderson K, Hultman CM, Ingvar $\mathrm{M}$, et al. Complement gene expression correlates with superior frontal cortical thickness in humans. Neuropsychopharmacology. (2018) 43:525-33. doi: 10.1038/npp.2017.164

10. Callezi C, Wuillemin WA, Zeerleder S, Redondo M, Eisele B, Hack CE. C1-Esterase inhibitor: an anti-inflammatory agent and its potential use in the treatment of diseases other than hereditary anioedema. Pharm Rev. (2000) 52:91-112.

11. Stevens B, Allen NJ, Vazquez LE, Howell GR, Christopherson KS, Nouri N, et al. The classical complement cascade mediates CNS synapse elimination. Cell. (2007) 131:1164-78. doi: 10.1016/j.cell.2007.10.036

12. Stephan AH, Barres BA, Stevens B. The complement system: an unexpected role in synaptic pruning during development and disease. Annu Rev Neurosci. (2012) 35:369-89. doi: 10.1146/annurev-neuro-061010-113810

13. Gorelik A, Sapir T, Haffner-Krausz R, Olender T, Woodruff TM, Reiner O. Developmental activities of the complement pathway in migrating neurons. Nat Commun. (2017) 8:15096. doi: 10.1038/ncomms15096
14. Gorelik A, Sapir T, Woodruff TM, Reiner O. Serping1/C1 inhibitor affects cortical development in a cell autonomous and non-cell autonomous manner. Front Cell Neurosci. (2017) 11:169. doi: 10.3389/fncel.2017. 00169

15. Coulthard LG, Hawksworth OA, Li R, Balachandran A, Lee JD, Sepehrband F, et al. Complement $\mathrm{C} 5 \mathrm{aR} 1$ signaling promotes polarization and proliferation of embryonic neural progenitor cells through PKCל. J Neurosci. (2017) 37:5395407. doi: 10.1523/JNEUROSCI.0525-17.2017

16. Denny KJ, Coulthard LG, Jeanes A. C5a receptor signaling prevents folate deficiency-induced neural tube defects in mice. J Immunol. (2013) 190:34939. doi: 10.4049/jimmunol.1203072

17. Coulthard LG, Hawksworth OA, Conroy J, Lee JD, Woodruff TM. Complement C3a receptor modulates embryonic neural progenitor cell proliferation and cognitive performance. Mol Immunol. (2018) 101:176-81. doi: 10.1016/j.molimm.2018.06.271

18. Coulthard LG, Hawksworth OA, Woodruff TM. Complement: the emerging architect of the developing brain. Trends Neurosci. (2018) 41:373-84. doi: $10.1016 /$ j.tins.2018.03.009

Conflict of Interest: The authors declare that the research was conducted in the absence of any commercial or financial relationships that could be construed as a potential conflict of interest.

Copyright $\odot 2019$ Coulthard and Woodruff. This is an open-access article distributed under the terms of the Creative Commons Attribution License (CC BY). The use, distribution or reproduction in other forums is permitted, provided the original author(s) and the copyright owner(s) are credited and that the original publication in this journal is cited, in accordance with accepted academic practice. No use, distribution or reproduction is permitted which does not comply with these terms. 